\title{
KÖRKIVÁGÁSSAL GYENGÍTETT LEMEZ MEGERŐSÍTÉSÉNEK VÉGESELEMES VIZSGÁLATA
}

\author{
Kiss László \\ BSc hallgató, Miskolci Egyetem, Müszaki Mechanikai Intézet \\ 3515 Miskolc, Miskolc-Egyetemváros, e-mail: laszlokiss706@gmail.com \\ Szirbik Sándor \\ egyetemi docens, Miskolci Egyetem, Müszaki Mechanikai Intézet \\ 3515 Miskolc, Miskolc-Egyetemváros, e-mail: sandor.szirbik@uni-miskolc.hu
}

\begin{abstract}
Absztrakt
A funkcionális követelményként szükséges kivágások gyengitik a héjszerkezetek érintett részeit igy csökkentve a szerkezeti integritást. Ezt többféleképpen is kompenzálni lehet, igy a kivágás peremét megerösitö valamilyen toldalék felhelyezésével is, hogy ezáltal a kivágás közvetlen környezete továbbra megfeleljen az elöirt szilárdsági, rezgéstani és stabilitási követelményeknek. A dolgozat egy köralakú kivágás megerösitett peremének végeselemes vizsgálatakor felmerülö egyes kérdésekkel foglalkozik vizsgálva a geometriai paraméterek hatását, összevetve az eredményeket a megerösités nélküli koncentrikus körkivágással gyengitett lemez esetén számitott értékekkel.
\end{abstract}

Kulcsszavak: köralakú kivágás, egyszerü alátámasztás, VEM, kritikus erö, stabilitásvesztés

\begin{abstract}
The necessary cutouts are in a thin-walled structure as functional requirement which weaken the affected part of the structures thus compromising the structure's integrity. This effect can be reduced by attaching a portion reinforcing the edge of the cutout, so that in the vicinity of the cutout the required strength, vibration and stability requirements are met. This paper is devoted to some issues of the finite element analysis of the reinforcement of the edge of a circular cutout by examining the effect of geometrical parameters and to compare to the values formed in the case of a steel plate with unreinforced concentric circular cutout.
\end{abstract}

Keywords: circular cutouts, simply support conditions, FEA, critical force, loss of stability

\section{Bevezetés}

A hidegen alakított acéllemezekből felépített esetleg merevítővázzal is rendelkező szerkezetek, valamint egyéb héjszerkezetek tervezésekor gyakori, hogy a szerkezeti kialakításon technológiai okokból, vagy funkcionális követelményként különböző méretü és kialakítású kivágások elhelyezése szükséges, amelyek a vékonyfalú héjnak [1] tekintett szerkezeti részek integritását lokálisan is kedvezötlenül befolyásolják. Az ilyen héjszerkezetek tervezése, így stabilitásvesztésüknek megelőzése [2] széles alkalmazási területen, mint például az építőipar, repülőgépipar, energiaipar [3], autógyártás és a hajóépítés [4] jelent kihívást, ahol mindig szükség van az elektromos kábelek, csövek és egyéb szerkezeti elemek számára szükséges nyílások létrehozására. További kérdések merülnek fel ilyen szerkezetek esetén, ha élettartamuk alatt magas hőmérsékleten is üzemelnek. 
A lemezek általában sajátsíkjukba eső nyomásnak, hajlításnak és nyírásnak, valamint síkjukra meröleges nyomásnak pl. hidrosztatikus nyomásnak stb. vannak kitéve, amelyek statikus vagy dinamikus terhelések is lehetnek. A kialakításukban lemezszerü gépészeti elemek tervezéskor használatos hagyományos eljárások általában ezen alapfeladatok, azaz a peremen elöírt elmozdulási és feszültségi peremfeltételekhez tartozó ismert megoldásokon alapulnak. Jelen dolgozat is egy ilyet tárgyal alapvetően szilárdságtani és stabilitási vizsgálatok szempontjából. Héjak, lemezek stabilitásvizsgálatakor a stabilitásvesztésre hajlamos szerkezet, így például a sajátsíkjában nyomó igénybevételnek kitett lemez egyensúlyi helyzetének stabilitását vizsgáljuk. A feladat kitüzésekor általában rugalmas alakváltozást tételezünk fel, így az egyensúlyi helyzet a potenciális energia minimuma a stabilitás szükséges és elégséges feltétele [1].

A kivágások szerkezet gyengítő hatását közvetlenül a kivágási perem és környezetének megerösítésével kompenzálhatjuk, hogy ezáltal megfeleljen a szerkezetre elöírt szilárdsági, rezgéstani és stabilitási követelményeknek [2], [3], [4]. Ez belsővázzal, vagy tartóbordákkal történő megerősítéssel [5] is megoldható, viszont annak költsége is nagyobb lehet. Dolgozatunkban bemutatásra kerül a köralakú kivágás geometriai paraméterének, az átmérőnek kitüzött feladatra gyakorolt hatása, és a kivágási perem megerősítésének a szilárdságtani állapotra gyakorolt kedvező hatásának vizsgálata adott geometriai paraméterekkel bíró, téglalap alakú, koncentrikus körkivágással gyengített lemez esetén.

A kitűzött feladatok vizsgálatakor az utóbbi évtizedek legjobban terjedő szimulációs módszere, a nagyhatékonyságú végeselemes analízis (FEA) kerül alkalmazásra [7], [8]. A numerikus mechanikában beálló gyors fejlődés, köszönhetően a számítógépi kapacitás és sebesség nagymértékü növekedésének, valamint a grafikai müveletek megszervezhetőségének, ad lehetőséget a fizikai jelenségek jobb modellezésére, azaz a kitüzött mechanikai feladatok sokoldalú elemzésére. A felmerülő müszaki problémák mechanikai modellje többnyire parciális differenciálegyenletek formájában jelentkezik, melyek egzakt megoldása sok esetben nem áll rendelkezésre. Ilyen jellegü feladatok esetén a numerikus szimulációk kerültek előtérbe. A numerikus megoldás során a keresett helytől és vagy időtől függő függvények, tenzormezők stb. a feladat geometriájának véges számú részei, végeselemei felett ún. approximációs függvények segítségével közelíthetők, majd az illesztési feltételek ismerete eredményezi a teljes tartományra vonatkozó közelítést, melyben a leíró paramétereket valamilyen hibaelvből, variációs elvből származó algebrai egyenletrendszer révén határozhatók meg.

\section{Feladat és a vonatkozó peremfeltételek}

A vizsgált körkivágással meggyengített, állandó $t$ vastagságú, saját síkjában az 1 . ábrán látható módon terhelt téglalap alakú lemez $a=200 \mathrm{~mm}$ és $b=100 \mathrm{~mm}$ befoglaló méretekkel rendelkezik és egy centrikusan elhelyezett $d$ átmérőjü köralakú kivágással gyengített, amely a kivágási pereménél $h=5 \mathrm{~mm}$ magasságú és $t$ lemezvastagsággal azonos vastagsági mérettel készített peremmerevítővel, azaz csődarabbal lesz megerősítve.

A téglalap alakú lemez minden oldalélén előírt elmozdulási peremfeltételek akadályozzák a középfelület $z$ irányú elmozdulását, de lehetőséget adnak a lemez pontjainak a lemez sajátsíkjában történő elmozdulásra. A középfelületi normálisok tetszőleges elfordulása azonban megengedett lesz, ezért ezt biztosítandó a peremen fellépő hajlító nyomaték értéke nulla, azaz a peremet külső erőpár nem terheli. Ezt a szakirodalomban szokás simple support conditions on all the edges (SSSS) elnevezéssel illetni és a perem mentén az 1. ábrán látható módon jelölni. 


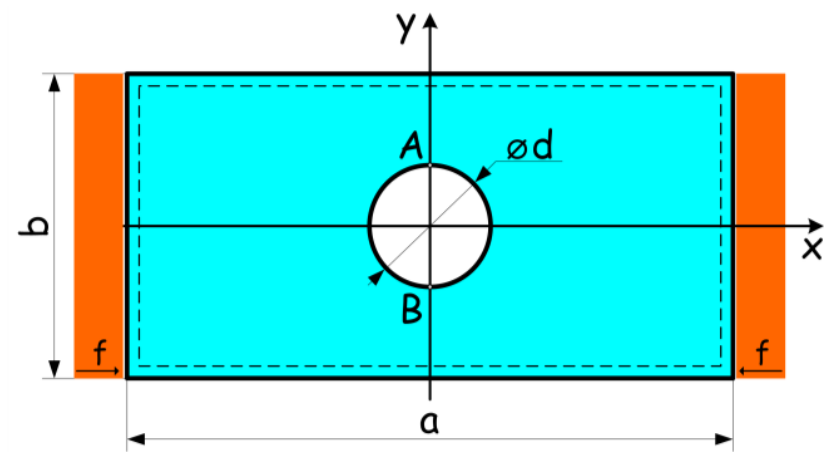

\section{1. ábra. Köralakú kivágással gyengitett lemez peremén alátámasztással}

A kitűzött elmozdulási peremfeltételt, illetve a kerületi feltételt, hogy nem lép fel erőpár az $x=-a / 2$ és az $x=a / 2$ koordinátájú megtámasztott széleken a

$$
w=0, \quad \frac{\partial^{2} w}{\partial x^{2}}=0,
$$

az $y=-b / 2$ és az $y=b / 2$ koordinátájú széleken pedig a

$$
w=0, \quad \frac{\partial^{2} w}{\partial y^{2}}=0
$$

elöírt egyenletek biztosítják, ahol $w=w(x, y)$ jelöli a $z$ irányú elmozdulást. A vonatkozó, az (1), (2) peremfeltételeket kielégítő megoldás egy kétváltozós függvény az alábbi

$$
w_{o}(x, y)=\sum_{i, j=1}^{\infty} C_{i j} \sin \frac{i \pi x}{a} \sin \frac{j \pi y}{b}
$$

alakban adható meg, ahol $C_{i j}$ tetszőleges állandót jelöl [1].

A feszültségi peremfeltételek az 1. ábrán látható módon az $x=-a / 2$ és az $x=a / 2$ koordinátájú oldaléleken állandó, vonalmentén egyenletesen megoszló, narancs színnel megfestett, $f$ intenzitású erőrendszer által elöírt terheléseként jelentkeznek, amelyek a lemezt sajátsíkjában, $x$ irányban nyomják. Az egyszerüség végett $f=1 \mathrm{~N} / \mathrm{mm}$ választással éltünk és erre vonatkozóan a lemez feszültségi állapotának elemzése végett numerikus szimulációkat végeztünk, amelyekben a paramétervizsgálat történt a kivágás $d$ átmérőjére nézve.

Az így felvett, egyébként önegyensúlyi terhelés esetén a lemez stabilitásvesztésre is hajlamos, tehát síkalakjának stabilitása vizsgálható és egyesesetekben rá analitikus megoldás is létezik. Az (1) és (2) feltételekkel alátámasztott téglalap alakú lemez esetén, ha az sajátsíkjában az $x=-a / 2$ és az $x=a / 2$ koordinátájú éleken keresztül nyomást szenved, de a fennmaradó, két $y=-b / 2$ és az $y=b / 2$ koordinátákkal adott peremek terheletlen maradnak, akkor

$$
f_{k r}=k \frac{\pi^{2} E t}{12\left(1-v^{2}\right)}\left(\frac{t}{b}\right)^{2}
$$


kritikus terhelés adódik, ahol $k=4$ az adott terhelési esethez tartozó (az (1), (2) és (3) összefüggésekből kiindulva minimum keresés útján nyert) horpadási tényezőt, az $E$ a Young-féle rugalmassági modulust, a $v$ pedig a Poisson-számot jelöl. Amennyiben a lemez egy $d$ átméröjü középpontosan 1 . ábrán látható módon elhelyezett köralakú kivágással gyengített akkor a kritikus terhelés

$$
f_{k r, d}=k_{d} \frac{\pi^{2} E t}{12\left(1-v^{2}\right)}\left(\frac{t}{b}\right)^{2}
$$

vonalmentén megoszló erőrendszer állandó intenzitása szintén megadható az adott terhelési esethez tartozó, új $k_{d}$ horpadási tényező bevezetésével, amely egy numerikusan meghatározható érték lesz. Ha a kivágás pereme megerősítést kap, akkor annak hatása a szerkezet stabilitásának alakulására analitikusan már végképp nem adható meg és kizárólag numerikus szimuláció útján megállapítható.

\section{Végeselemes vizsgálatok}

A héjelemekkel történő modellezés az eredeti háromdimenziós geometriát a modellalkotás során a héj középfelületére történő leképezésével helyettesíti, ahol a végeselemes felbontás minden csomópontja normálist reprezentál és minden egyes csomóponthoz 6 aktív szabadságfok van rendelve. Általánosságban megállapítható, hogy a numerikus modellezésben használt héjmodellhez szükséges erőforrásigény a háromdimenziós kontinuum modellhez képest a kevesebb szabadságfok eredményeként létrejövő kisebb méretű feladat (lineáris egyenletrendszer) okán nagyban lecsökken, továbbá a szimulációs eredmények az alkalmas megválasztott elemszám mellett megfelelő pontossággal is bírnak.

Az Abaqus-ban szokásos választás és az ilyen típusú feladatokban jól használható elemcsalád lineáris közelítés esetében a négy csomópontú S4R, kvadratikus interpoláció mellett pedig a nyolc csomópontú S8R héjelem [8], [9]. Megjegyzendő, hogy lineáris héjelemeket megfelelően nagy elemszámmal alkalmazva, azaz kis elemmérettel dolgozva is már elfogadható eredményeket kapunk. A kitüzött feladat végeselemes analízisében 2,5 $\mathrm{mm}$-es átlagos elemmérettel és S8R héjelemmel számoltunk, ellenörizve a megoldások konvergenciáját is. A köralakú kivágással rendelkező acéllemez lineárisan rugalmasként, azaz $E=2 \times 10^{5} \mathrm{MPa}$ rugalmassági modulussal és $v=0,25$ értékü Poisson tényezővel jellemzett anyagmodellel került megadásra a szimulációkban.

A maximális redukált feszültségek, az 1 . ábrán bejelölt $A$ és $B$ jelü pontokban ébrednek és a kivágás átméröjének növekedésével változnak. Az általunk lefutatott numerikus szimulációk eredményét, az elöírt $f=1 \mathrm{~N} / \mathrm{mm}$ terhelés esetében a 2 . ábrán jelenítettük meg, amelyen vízszintes tengelyen lévő, $d$ átmérőből és állandónak tekintett $b$ lemezszélességből számított viszonyszám függvényében van megállapítva egy szintén dimenziótalanított arány, amely az ébredő maximális redukált feszültség és a kivágás nélkül esetben számított maximális redukált feszültség hányadosa (kék szín). Az ábrán emellett egy hasonlóképp megállapított arány került rózsaszínü görbével szemléltetésre, amely a köralakú kivágás peremének lemezvastagsággal azonos falvastagságú és $h=5 \mathrm{~mm}$ magasságú csődarabbal végzett megerősítésének esetére vonatkozik.

A 2. ábrából kitűnik, hogy a kivágás peremén megjelenő feszültségtorlódások lényegesen növelik az ébredő feszültség maximális értékét, és ezáltal $A$ és $B$ pontok környezetében indulhat meg a szerkezet tönkremenetele, így a kivágás peremének megerősítése ebből a szempontból is valóban indokolt. 


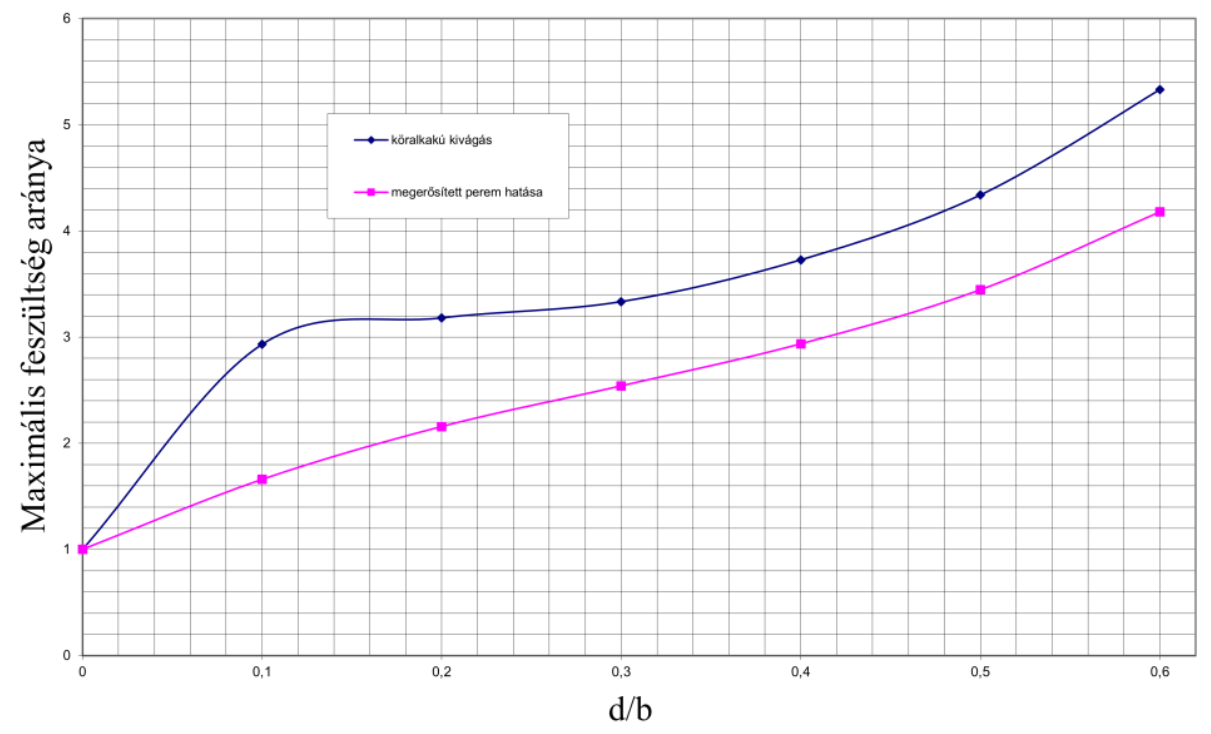

2. ábra. Maximális redukált feszültségek aránya d/b függvényében

A numerikus szimulációkból továbbá az is látható, itt most külön ábrán nem szemléltetve, hogy a merevítés átrendezi a feszültségeloszlást és emellett nagymértékben csökkenti az ébredő maximális redukált feszültség értékét (a 2. ábrán rózsaszínnel jelölt görbe), amely szintén a megerősítés csatlakozási peremén ébred. Értelemszerüen a csatlakozási él esetleges lekerekítése ott még tovább simítana feszültségeloszláson, mert így a feszültségtorlódások egyik okát megszüntetve még kisebb maximális redukált feszültségeket eredményez. A külső peremek támaszainak jellege is erős hatást gyakorol a kialakuló mechanikai állapotokra [1], [6]. A vizsgált esetben tehát, a 2. ábrán látható módon a peremerősítés hatása észrevehető mértékben csökkenti a feszültségek maximális értékét.

A modal analízishez hasonló eljárással (a programban [7] Procedure type: Linear perturbation: Buckle) numerikusan számítható a héjszerkezet stabilitásvesztésének vizsgálatához, a tökéletes geometria megzavarásához szükséges imperfekció alapját is adó, stabilitásvesztéshez tartozó sajátalak, melyet befolyásol az alátámasztás módja és a rezgéstani alkalmazásoktól eltérő módon maga a terhelési mód is, amelynek nagyságát célszerú itt már egységnyinek megválasztani. A stabilitásvesztés szempontjából numerikusan elemzésre került $d / b$ függvényében az ismertetett feladat. Az 1 . táblázat $t=2$ $m m$ és $t=4 \mathrm{~mm}$ lemezvastagsággal is véve közli a sajátértékek közül a legkisebb első hármat a választott $f=1 \mathrm{~N} / \mathrm{mm}$ referenciaterhelés esetén. Elmondható, hogy a sajátértékfeladatok megoldása során a sajátérték számítása általában pontosabban végezhetö, mint a sajátvektorré és így a sajátértékekből célszerü előállítani a stabilitásvesztéshez tartozó sajátalakokat (buckling shape modes). A feladat megoldására altér iterációs technikát, vagy Lánczos-módszert alkalmazhatunk a szoftverben. Nagyobb méretü feladatnál az utóbbi alkalmazása a célravezetőbb [7], [9]. A megoldások közül az elsőt, a legkisebbet, a legkorábban bekövetkezöt, a legelöször stabilitásvesztést okozót célszerü alkalmazni arra, hogy az idealizált alakot imperfekcióval, azaz geometriai tökéletlenséggel lássuk el ezáltal előidézve a stabilitásvesztést, azaz lehetővé tenni a horpadás numerikus modellezhetőségét Riks-módszerrel. 
1. táblázat. A sajátértékek alakulása körkivágás méretváltozásának függvényében

\begin{tabular}{|c|c|c|c|c|c|}
\hline$d[\mathrm{~mm}]$ & $d / b$ & $t[\mathrm{~mm}]$ & $\lambda_{1}$ & $\lambda_{2}$ & $\lambda_{3}$ \\
\hline 0 & 0 & 2 & 648,74 & 868,26 & 1163,7 \\
\hline & & 4 & 5075,8 & 6857,8 & 9044,0 \\
\hline 10 & 0,1 & 2 & 638,97 & 860,52 & 1148,7 \\
\hline & & 4 & 5001,2 & 6789,8 & 8929,3 \\
\hline 20. & 0,2 & 2 & 621,28 & 849,12 & 1147,4 \\
\hline & & 4 & 4866,3 & 6683,2 & 8928,4 \\
\hline 30 & 0,3 & 2 & 615,36 & 852,87 & 1183,6 \\
\hline & & 4 & 4817,4 & 6687,4 & 9216,0 \\
\hline 40 & 0,4 & 2 & 630,03 & 875,81 & 1270,7 \\
\hline & & 4 & 4919,8 & 6819,3 & 9900,8 \\
\hline 50 & 0,5 & 2 & 665,28 & 903,18 & 1488,0 \\
\hline & & 4 & 5171,7 & 6950,3 & 11599.0 \\
\hline 60 & 0,6 & 2 & 722,79 & 923,00 & 1763,0 \\
\hline & & 4 & 5585,4 & 7004,7 & 13171,0 \\
\hline
\end{tabular}

A Riks algoritmus alkalmazásával, azaz egy további végeselemes szimulációval (a programban [7] Procedure type: General: Static, Riks) lehet ezekután meghatározni a stabilitás vesztést okozó kritikus $f_{k r}$ értéket. Jelen esetben, a sajátsíkjában lévő lemez esetén úgy jelentkezik a stabilitásvesztés, hogy a kritikus terhelés elérésekor síkra merőleges elmozdulás hirtelen, nagymértékben megnő és ennek következtében hirtelen horpadás jelenik meg mindenféle látható előjel nélkül a lemezen, azaz tulajdonképpen egy új egyensúlyi alakba hirtelen pattan át a szerkezet.

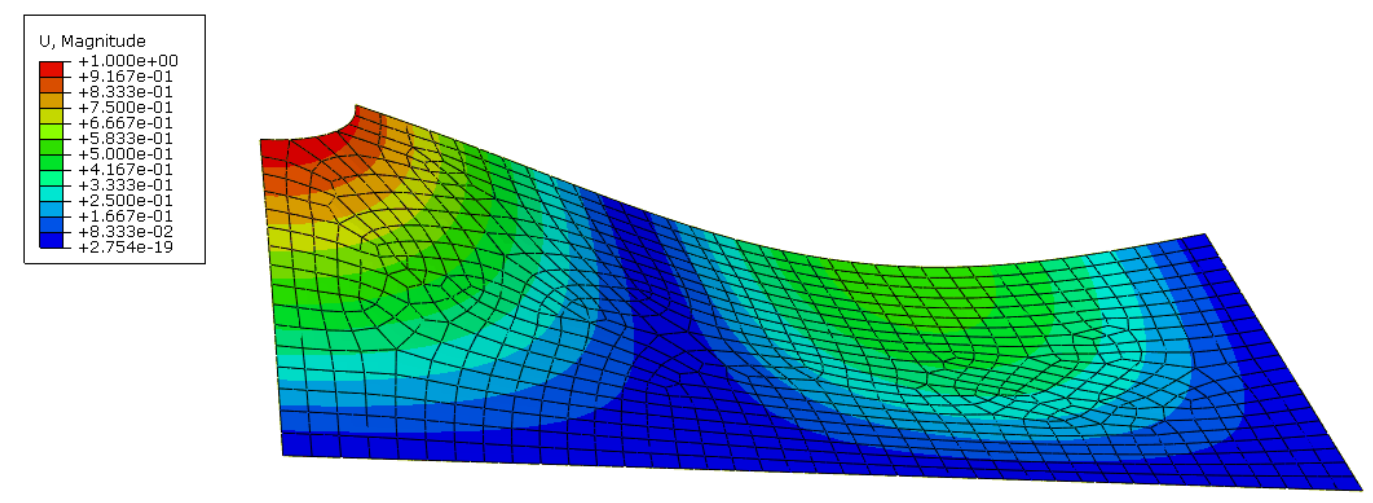

3. ábra. A $d / b=0,2$ esetén a $\lambda_{1}=621,28$ értékhez tartozó elsö saját alak

A feladat megoldását a $d$ átmérö függvényében végezve nyert adatokat összefoglaló 1 . táblázatból, a $d / b=0.2$ és $t=2 \mathrm{~mm}$ lemezvastagság mellett álló $\lambda_{l}$ értékhez tartozó sajátalakot a 3. ábra szemlélteti, amely egy már normált alak, így a legnagyobb elmozdulás rajta egységnyi. A megállapított sajátalak tetszőleges konstanssal, általában a geometria jellemző méretének bizonyos százalékával történő felszorzása után alkalmazható a végeselemes programban, hogy a Riks-módszer segítségével megrajzoljuk terhelésekhez tartozó egyensúlyi utat. A numerikus megoldás során a feladat meglévő szimmetriáit 
is kihasználtuk, így a 3. és 4. ábrákon az 1. ábrán berajzolt koordinátarendszer szerint véve a lemez negyedik sík negyedbe eső negyede látható. A többi sajátalak természetesen hasonlóképpen megjeleníthető és felhasználható további számításokban. A perem egy egyszerủ megerősítése után a 4. ábrán látható ismét a $d / b=0.2$ esetre, $t=2 \mathrm{~mm}$ lemezvastagságnál, de már $h=5 \mathrm{~mm}$ magasságú perem alkalmazása esetén az első sajátalak, melyen jól látszik a merevítés hatása.

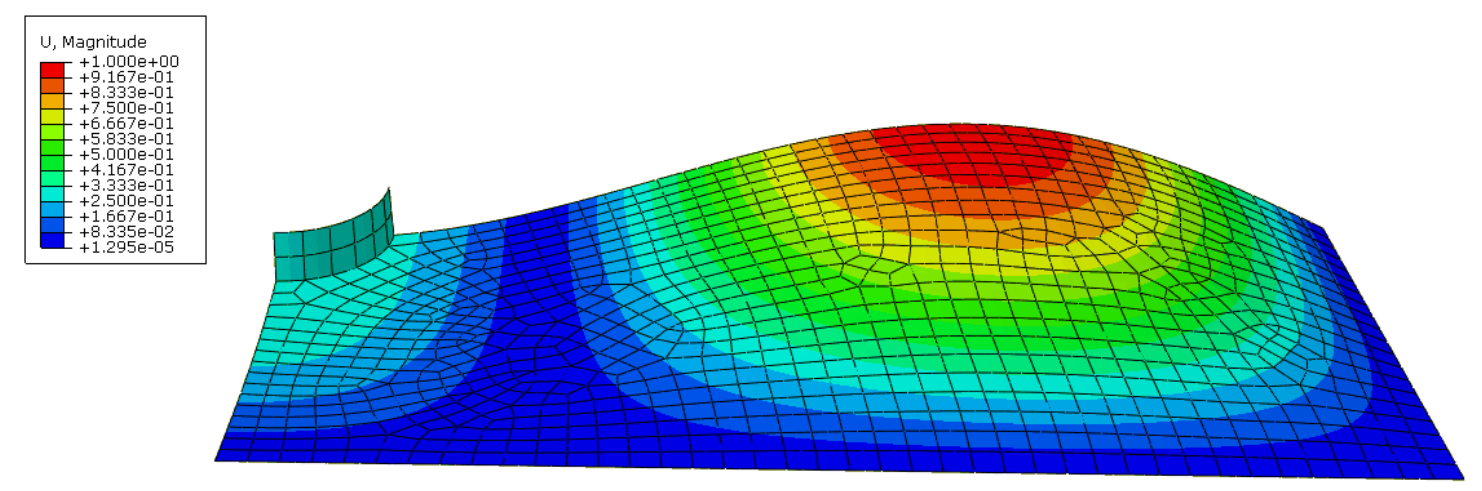

4. ábra. A $d / b=0,2$ esetén a $\lambda_{1}=679,33$ értékhez tartozó elsö saját alak

A kritikus terhelés megállapítása történhet egyszerübb módon a programba bevitt geometria és anyagjellemzők mellett a referenciaterhelés felvétele után számított sajátértékek és referenciaterhelés szorzatából is. A Riks algoritmus alkalmazásával azonban egy erö-elmozdulás diagramon keresztül a szerkezet egyensúlyi útja kerül bemutatásra, amely elemzéséből állapítható meg a stabilitásvesztés.

\section{4. Összefoglalás}

A bemutatott feladat végeselemes szimulációk által került vizsgálatra, amelyben a köralakú kivágás átmérőjének változása és az állandó lemez szélesség hányadosa segítségével vizsgáltuk a feszültségi állapot és a stabilitásvizsgálat numerikus szimulációjának egyes kérdéseit. A numerikus szimulációk további peremmegerősítési módok, kialakítások esetében is a mérnöki gyakorlatban jól használható diagrammok megrajzolásához vezetnek. A szerkezet másféle megtámasztása, azaz a problémához egyéb további peremértékfeladatok [1] kitüzése is lehetséges, mivel az alkalmazott végeselemes tárgyalásmód, illetve azt alkalmazó kereskedelmi végeselemes [7] szoftver e tekintettben is nagy rugalmasságot mutat. A bemutatott példa is alátámasztja, illetve az idézett munkákból is kitünik, hogy a kivágási perem közvetlen megerősítése kedvezően hat mind a szilárdságtani, mind a stabilitási szempontokra, és ezek vizsgálatát sorozatszámításokat végezve célszerü összegezni.

\section{Köszönetnyilvánítás}

A cikkben ismertetett kutató munka az EFOP-3.6.1-16-2016-00011 jelü „Fiatalodó és Megújuló Egyetem - Innovatív Tudásváros - a Miskolci Egyetem intelligens szakosodást szolgáló intézményi fejlesztése" projekt részeként - a Széchenyi 2020 keretében - az Európai Unió támogatásával, az Európai Szociális Alap társfinanszírozásával valósul meg. 


\section{Irodalom}

[1] Kozák, I.: Szilárdságtan III., Műszaki könyvkiadó, Budapest, 1976.

[2] Komur, M. A., Sonmez, M.: Elastic buckling of rectangular plates under linearly varying inplane normal load with a circular cutout, Mechanics Research Communications 35(6), pp. 361-371, 2008. https://doi.org/10.1016/j.mechrescom.2008.01.005

[3] Dimopoulos, C. A., Gantes C. J.: Numerical methods for the design of cylindrical steel shells with unreinforced or reinforced cutouts, Thin-Walled Structures 96, pp. 11-28, 2015. https://doi.org/10.1016/j.tws.2015.07.024

[4] Kim, J. H., Jeon, J. H., Park, J. S., Seo, H. D., Ahn, H. J., Lee, J. M.: Effect of reinforcement on buckling and ultimate strength of perforated plates, International Journal of Mechanical Sciences 92, pp. 194-205, 2015. https://doi.org/10.1016/j.ijmecsci.2014.12.016

[5] Virág, Z.: Optimum design of stiffened plates for different loads and shapes of ribs, Journal of Computational and Applied Mechanics, 5(1), pp, 165-179, 2004.

[6] Benguediab, S., Kettaf, F. Z., Benguediab, M.: Buckling of rectangular plates with different central holes, Mechanics and Mechanical Engineering Vol. 21(4), pp. 885-895, 2017.

[7] Abaqus 6.13 online documentation, Dassault Systems, 2015.

[8] Bathe, K. J.: Finite Element Procedures, Prentice-Hall Inc. Englewood Cliffs, New Jersey, 1996.

[9] Gönczi, D., Baksa, A., Kiss, L. P.: Aluminium palackok nyakazási lépéseinek és stabilitásvesztésének modellezési sajátosságai, Multidiszciplináris tudományok, 9. kötet. 2 sz. pp.56-63, 2019. https://doi.org/10.35925/j.multi.2019.2.9 